\title{
ROMANCE E MEMÓRIA: \\ RETRATOS DA PRIMEIRA GUERRA MUNDIAL EM PASSEIO AO FAROL DE VIRGINIA WOOLF
}

\section{NOVEL AND MEMORY: \\ PORTRAITS OF THE FIRST WORLD WAR IN A TOUR OF THE LIGHTHOUSE OF VIRGINIA WOOLF}

\author{
Giancarlo Moreira Rodrigues ${ }^{1}$ \\ Luciana Brito ${ }^{2}$
}

\begin{abstract}
Resumo: O presente estudo tem por objetivo apresentar os efeitos da primeira guerra mundial no romance Passeio ao farol, de Virginia Woolf, por meio de teóricos que discutem a relação entre memória, história e literatura, como é o caso de Kramer, Halbwachs, Ricceur, Heller, Bosi, Lima, Benjamin, dentre outros. Vale ressaltar que, em Passeio ao farol, a escritora inglesa expressa, por meio de monólogos interiores, as tensões e destruições provocadas pela guerra, além de realizar várias indagações a respeito da humanidade e seus valores. A primeira guerra mundial se tornaria um fator de crise no contexto do homem do século XX, pois o mesmo que efetivou inovações nos saberes também destruiu os seus semelhantes por interesse e poder. Virginia Woolf, imbuída desta perspectiva crítica, desconstrói a figura do homem tradicional em seu romance e apresenta um novo ser, cuja representação é fragmentada e caótica. Esta pesquisa, cujo caráter é comparativo, tem o intuito de averiguar tais alterações.
\end{abstract}

Palavras-chave: memória; romance; primeira guerra mundial; Virgínia Woolf.

\begin{abstract}
Present study has since objective presents the effects of the first world war in the novel To the lighthouse, of Virginia Woolf, through theoreticians who discuss the relation of the memory, history and literature, since it is the case of Kramer, Halbwachs, Ricceur, Heller, Bosi, Lima, Benjamin, among others. It costs standing out that, in to the lighthouse, the English definite writer, through inner monologues, the tensions and destruction provoked by the war, besides carrying out several investigations as to the humanity and his values. The First World War would become a factor of crisis in the context of the man of the century XX, since the same thing that brought innovations into effect you in knew; there was the same thing what to destroy his similar for interest and power. Virginia Woolf imbued with this critical perspective, deconstructs the figure of the traditional man and it presents a new one to be whose representation is broken up and chaotic. This research, whose character is comparative, aims to investigate such changes.
\end{abstract}

Keywords: memory; novel; first world war; Virginia Woolf.

\footnotetext{
${ }^{1}$ Graduado em letras/inglês pela Universidade Estadual do Norte do Paraná. E-mail: Gi_ptal@hotmail.com

${ }^{2}$ Doutora em Letras pela Universidade Estadual Paulista, docente do Centro de Letras, Comunicação e Artes da Universidade Estadual do Norte do Paraná e do Programa de Pós-Graduação em Letras da Universidade Estadual de Londrina. E-mail: 1brito@uenp.edu.br
} 


\section{Introdução}

Caótico, assombroso, confuso e desconexo. Essas são algumas características que o romance moderno recebe de leitores iniciantes, ao se aproximarem do imenso oceano que compõem esta fase do romance na história da literatura. Esses julgamentos não estão distantes da verdade, no entanto, carecem de um conhecimento mais profundo do mesmo.

Por isto, para compreender esta nova etapa do romance, é necessário saber os motivos que o levaram a se comportar desta forma e as causas que fizeram com que rompesse radicalmente com sua estrutura tradicional. Tendo por base essas questões, o presente estudo procura explanar o processo de modificação do romance, partindo da ruptura dos seus elementos mais básicos, até a experimentação de novas técnicas de captação de sensações externas e internas.

Além disso, serão apresentadas as causas que levaram a tais mudanças e sua relação com a memória histórica. Entre os inúmeros romances e escritores que compõem esta nova fase, destaca-se a escritora inglesa Virginia Woolf. Em seu romance Passeio ao Farol, de 1927, a romancista rompe com as estruturas clássicas da narrativa e emprega uma nova forma de captar as sensações e a realidade, ela aplica a sondagem psíquica. É através desta que os leitores conhecerão o mundo como de fato é, ou seja, uma dimensão contraditória e caótica cujos habitantes trucidam-se mutuamente.

No entanto, para entender o motivo da busca de novas técnicas para retratar o homem e sua realidade, é preciso explorar os efeitos da Primeira e Segunda Guerra Mundial. As duas Grandes Guerras destruíram as bases sociais e antropológicas existentes, deixando o homem um ser sem identidade, realidade ou expectativa, tornando-se estranho a si mesmo, o que levou Virginia Woolf bem como os demais escritores deste período a romperam com as formas tradicionais. Era necessário um romance que fosse semelhante ao homem daquele momento, um ser sem nome, sem realidade, cujo mundo é desconexo e mortal. Logo, em Passeio ao Farol essa memória das guerras é visível, porém, não de forma descritiva, aparecendo por meio do próprio processo de ruptura e experimentação presentes na narrativa.

\section{0 século das rupturas: o despertar da crise}

No início do século XX, ocorreram várias indagações a respeito do gênero romance. Argumentaram que ele estaria passando por uma crise e poderia deixar de existir. Walter Benjamin, por exemplo, em seu ensaio intitulado "O narrador: considerações sobre a obra de 
Nikolai Leskov", que faz parte de uma reunião de ensaios do crítico alemão publicada em uma edição brasileira intitulada Magia e técnica, arte e política: ensaios sobre literatura e história da cultura, discorre sobre alguns acontecimentos e invenções dos tempos modernos.

Tais inovações modernas contribuíram para o enfraquecimento da arte narrativa como, por exemplo, o estancamento do processo de transmissão das experiências (que representou a impossibilidade de continuidade das narrativas tradicionais) e a ênfase dada à questão da individualidade, o que favoreceu o surgimento de narrativas de cunho psicológico que destruíram a coerência e a linearidade do enredo tradicional.

Ora, de fato, no despertar do século passado, esse gênero passou por um momento de mudança. Todavia, resta saber que tipo de romance passou por crise e quais foram os motivos que levaram a tais alterações. Dentro da perspectiva comentada a cima, é possível salientar que foi o romance da segunda metade do século XIX que entrou em colapso. Seu objetivo havia tornando-se incoerente ante as novidades tecnológicas, o desenvolvimento das novas teorias filosóficas e psicológicas e as atrocidades da primeira guerra mundial. O mundo havia mudado, em especial o homem que nele residia.

Logo, aquela forma de narrativa criada por Zola, cujo alicerce era pautado nos estudos científicos de Claude Bernard, que tinha o propósito de fazer do romance um laboratório e do romancista um experimentador, tornou-se inverossímil:

\footnotetext{
$\mathrm{O}$ enredo e a presença do narrador onipresente e onisciente, à moda grandiloquente de um Balzac, foram sendo reduzidos. O romance, como se disse, "entrou em crise". Não haveria, porém, uma única solução, como Zola acreditou durante muito tempo. Várias possibilidades surgiram, dependentes das personalidades e de seus criadores e não de modelos. Algumas, por suas dificuldades, foram rejeitadas pela maioria dos leitores e só encontraram adeptos entre os especialistas (MANZANO, 2008, p.150).
}

Consequentemente, a tentativa descritiva e observadora dos realistas também se tornara inexequível àquele contexto histórico. A própria realidade social comprovou que a vida do homem não é algo linear ou ordenado, mas complexo, destruidor e indeterminado. Para tanto, vale lembrar um trecho do romance de Agatha Christie, que de modo perspicaz, corrobora com esta visão:

[...] Não estou convencido de que as histórias da vida real têm começo e fim, na realidade. Experimente abordá-las de uma perspectiva mais ampla, e você vai ver que elas se estendem infinitamente pelo passado e se propagam inexoravelmente pelo futuro. É impossível dizer "Então foi isso" e passar uma régua (CHRISTIE, 2014, p. 20). 
Portanto, o que entrou em crise foram as narrativas de base naturalistas e realistas. Elas, como já foi mencionado, tornaram-se incoerentes ao ambiente social do século passado. Por isso, necessitava-se de uma nova forma de representar o homem e sua barbárie, no entanto, caberia ao romance dar início a esse processo. Mas, primeiro, ele teria que ir às cinzas de sua existência para renascer com uma outra estética, cuja base fosse mais coerente com a nova esfera social que se fundava.

Entre os diversos fatores que favoreceram a mudança do gênero romance, o mais agravante foi a Primeira Guerra Mundial de 1914-1918. Ela desfez toda a construção ideológica a respeito da identidade do homem, assim como sua realidade sócio histórica. $\mathrm{O}$ antigo lema da revolução francesa, que perdurou até o final do século XIX, perdera sua áurea racional perante a barbárie. De acordo com Hobsbawm:

Prontamente, muitos representantes da burguesia trataram de exonerar os ideais da razão, ciência, cultura, liberdade e ilustração, e procuraram manifestar à redenção dentro da guerra, do poder e dos instintos. Crise cultural e moral que se manifesta em Friedrich Nietzsche e Maurice Barrès (HOBSBAWM, 1996, p. 89).

Logo, o romance tradicional não poderia mais ser o representante dessa nova fase da humanidade, pois tanto o homem como a sociedade haviam perdido sua identidade:

\begin{abstract}
A eclosão da Primeira Guerra Mundial revelou a existência de uma situação nova e sem precedentes na história. A tremenda fúria destrutiva dos exércitos nacionais numa guerra total alterou, decisivamente, os sentidos que recobriam as palavras e os objetos, as tradições e os valores morais, a ciência e a razão, a barbárie e o progresso, o passado e o presente, as concepções de mundo e o poder (ZUIN, 2001, p. 69).
\end{abstract}

Devido à destruição causada pela guerra, as narrativas mudaram radicalmente para se adequar à nova realidade, por isso seus elementos microestruturais precisaram ser remodelados e até mesmo excluídos. Com isso, o narrador tradicional onisciente foi desfeito e deu lugar a um narrador calado, perdido, que tem medo do mundo que o cerca, um ser pobre de sabedoria e experiências (BENJAMIN, 1987).

Nem o tempo e o espaço seriam como antes, ambos foram fragmentados e distorcidos; os personagens perderam sua sensibilidade humana, resumindo-se a seres inomináveis. Como exemplo, vale citar o personagem Josef K. de O Processo, que nem nome tem mais. A Primeira Guerra Mundial inaugurou um novo momento para a civilização, sendo que Kafka, como participante desse período da história, teve intuições acerca de um mundo mais cruel, complexo e burocratizado que estava surgindo a partir daí. Em muitas das suas obras há a presença de 
personagens que retratam a desilusão frente a instituições que deveriam proteger e dar segurança ao homem. Uma delas seria a novela intitulada $\mathrm{Na}$ colônia penal, em que um infrator é condenado à morte por oficiais cuja doutrina resume-se à ideia de que a culpa não deve jamais ser colocada em dúvida e a execução da pena deve ser cumprida por uma máquina de tortura que escreve lentamente no corpo, com agulhas que o atravessam, a frase "Honra teus superiores".

Além destas alterações, foram utilizadas outras técnicas que enriqueceram esta nova forma de narrativa, como o antigo monólogo interior e novíssimo fluxo de consciência. Sendo assim, romance moderno se tornou a voz e o espelho do caos provocado pelo homem, por isto sua composição é complexa e desordenada:

O modernismo é, desde modo, uma literatura relativamente autônoma. Sofre com as dores do corpo inteiro e reflete as intervenções cirúrgicas que a guerra e a revolução representam. Mas guarda sempre uma autonomia que nenhum estilo literário, desde a renascença possuíra (CARPEAUX, 2011, p. 2454)

Ele adquiriu o mesmo espírito dos combatentes que voltavam da guerra. Ao invés de narrarem suas experiências bélicas e seus feitos heroicos, silenciaram-se e ocultaram para si todo o sofrimento experimentado:

\begin{abstract}
Os livros de guerra que inundaram o mercado literário nos dez anos seguintes não continham experiências transmissíveis de boca em boca. Não, o fenômeno não é estranho. Porque nunca houve experiências mais radicalmente desmoralizadas que a experiência estratégica pela guerra de trincheiras, a experiência econômica pela inflação, a experiência do corpo pela fome, a experiência moral pelos governantes. Uma geração que ainda fora à escola num bonde puxado por cavalos viu-se abandonada, sem teto, numa paisagem diferente em tudo, exceto nas nuvens, e em cujo centro, num campo de forças de correntes e explosões destruidoras, estava o frágil e minúsculo corpo humano (BENJAMIN, 1987, p.115).
\end{abstract}

Foram muitos os escritores que participaram deste novo ciclo, em cada país houve manifestações que compartilhavam este Zeitgesit destruidor. Vale lembrar alguns nomes, como Proust, James Joyce, Faulkner, André Gide, Samuel Beckett e Virgínia Woolf. De forma geral, as narrativas destes escritores, além de conter todas as características já citadas sobre o romance moderno, formam também o que se denomina de memória coletiva. Elas conservam as lembranças, depoimentos, e, de uma certa forma, as experiências vivenciadas por aqueles escritores no período da guerra: “A Primeira Guerra Mundial provocou profundas feridas na vida dos intelectuais que a viveram ou para aqueles que foram educados no interior da sociedade europeia em ruínas" (ZUIN, 2001, p.85). 
Logo, ao ler a produção literária dos escritores de vanguarda, os indivíduos contemporâneos são lembrados dos horrores daquela fase e, com isto, formulam suas lembranças apoiados nos relatos de outros que foram testemunhas, como diria Halbwachs:

[...] nossas lembranças permanecem coletivas, e elas nos são lembradas pelos outros, mesmo que se trate de acontecimentos nos quais só nós estivemos envolvidos, e com objetos que só nós vimos. 'E porque, em realidade, nunca estamos sós. Não é necessário que outros homens estejam lá, que se distingam materialmente de nós: porque temos sempre conosco e em nós uma quantidade de pessoas que não se confundem. (HALBWACHS, 1969, p. 16)

Dentre os escritores supracitados, Virginia Woolf é a romancista que realizou a junção do espírito modernista e a experiência da guerra com maestria. Ela foi uma das testemunhas oculares do genocídio que a Primeira Guerra Mundial causou, todas as tensões, angústias passaram aos seus olhos como uma tempestade atordoante ${ }^{3}$ :

\begin{abstract}
As árvores outonais, devastadas como estão, trajam o clarão de bandeiras esfarrapadas ardendo na escuridão dos frios porões de catedrais onde letras douradas sobre a páginas de mármore descrevem a morte na batalha e contam como, muito longe, os ossos se desbotam e queimam nas areias indianas (WOOLF, 2013, p.111).
\end{abstract}

Sendo assim, seus romances acabaram tornando-se produções densas, cuja estrutura estética é fragmentada "O escritor, como narrador de fatos objetivos, desaparece quase que completamente; quase tudo o que é dito aparece como reflexo na consciência das personagens do romance" (AUERBACH, 2009, p. 801).

O romance Passeio ao farol, de 1927, é uma das obras de Woolf que expressam as modificações ocorridas no gênero romance e apresenta os conflitos causados pela Primeira Grande Guerra. Basta observar, para tanto, a própria divisão capitular do romance, no qual o primeiro capítulo, intitulado "A janela”, corresponde ao pré-guerra, o segundo capítulo, "O tempo Passa", abarca o período de cinco anos da primeira guerra, e o terceiro, "O farol", corresponde ao pós-guerra ${ }^{4}$.

\footnotetext{
${ }^{3}$ As árvores outonais, devastadas como estão, trajam o clarão de bandeiras esfarrapadas ardendo na escuridão dos frios porões de catedrais onde letras douradas sobre a páginas de mármore descrevem a morte na batalha e contam como, muito longe, os ossos se desbotam e queimam nas areias indianas (WOOLF, 2013, p.111).

${ }^{4}$ Virginia Woolf dividiu o romance em três seções: "A Janela", "O Tempo Passa" e "O Farol". A primeira seção cobre o fim de tarde e a noite de um certo dia do mês de Setembro ("Era Setembro, afinal, meados de setembro, e passava das seis da tarde.":I,4) de um ano situado antes da Primeira Grande Guerra (1914-1918). A Segunda, a mais curta das três, cobre um período de dez anos, incluindo os cinco anos da Guerra, durante os quais a família Ramsay deixou de frequentar a sua casa de veraneio nas Ilhas Híbridas. A terceira cobre a manhã de um certo dia de um ano situado imediatamente após a Guerra (TADEU, 2013, p.211).
} 
Em outras obras da romancista inglesa, é possível encontrar seu ponto de vista sobre período histórico em que viveu, como o seu ensaio Um teto todo seu (2014), na qual imprime sua visão enquanto intelectual a respeito das consequências que a guerra trouxe à sociedade arcaica e conservadora de seu tempo, em outras palavras, a guerra não dizimou apenas aos homens nos campos de batalha, mas toda uma tradição conservadora:

Quando os canhões dispararam em agosto de 1914, será que o rosto dos homens e das mulheres pareceu tão feioso aos olhos uns dos outros a ponto de matar o romantismo? Há de ter sido um choque (particularmente para as mulheres, com suas ilusões sobre a educação e assim por diante) ver o rosto de nossos governantes à luz do fogo de artilharia. Tão eram eles- os alemães, os ingleses, franceses-, tão estúpidos! (WOOLF, 2014, p.21).

Esse mesmo posicionamento sobre a guerra não está explícito no romance Passeio ao farol, já que a própria desconstrução estrutural realizada por Woolf em seu romance já adotara este papel. Entretanto, isto não a afasta da relação da memória e história, mas, ao contrário, forma com ela a memória coletiva de um período dilacerado pelos horrores da guerra. Dessa forma, o romance de Virginia Woolf assumiu aquela tarefa reservada aos artistas do início do século XX: representar, por meio de sua arte, um homem mutilado e sem forças coletivas:

Era uma arte do desespero, fragmentada, fraturada, e que buscava retratar um mundo drasticamente estilhaçado em seu sentido e nas suas representações. Nesse mundo alterado, o artista procurava retratar o indivíduo mutilado e sem forças coletivas, que sobrevive impotente no interior de uma brutal e dilaceradora temporalidade histórica (ZUIN, 2001, p. 88).

Passeio ao farol corrobora com este novo anseio do romance, pois atestou que o gênero em questão não se achava em crise, mas em um processo de transformação. Sendo assim, as memórias da Primeira Grande Guerra não se encontram exclusivamente descritas no romance de Woolf, mas reside na própria ruptura e experimentação do mesmo.

\subsection{Ruptura e experimentação modernista em Passeio ao Farol}

O processo de ruptura, mencionado acima, testifica um fato inegável sobre o romance. Ele é um gênero complexo e multiforme, cuja ossatura não é calcificada nem seu cânone é acabado "[...] O romance está ligado aos elementos do presente inacabado que não o deixam se enrijecer. O romancista gravita em torno de tudo aquilo que ainda não está acabado (BAKHTIN, 
1988, p.417). Como já fora aludido, ele acompanha e adequa-se às transformações a que os homens passam dentro do seu sistema sócio-político com o transcorrer dos séculos. ${ }^{5}$

Sendo assim, o romance, com o nascer duma nova geração, rompe com suas estruturas antigas e experimenta novas estéticas, a fim de representar melhor a fase que se encontra. Passeio ao farol deu continuidade a este itinerário, começando por desfazer os elementos básicos da narrativa tradicional, ou seja, o conceito de cópia da realidade, de tempo, de espaço e de narrador. Isto foi necessário para que, de fato, o que se vivenciava externamente pudesse ser incorporado pelo romance. ${ }^{6}$

Logo, a primeira cisão foi com o conceito de realidade. Virgínia Woolf não tinha a preocupação de detalhar os eventos do mundo real, mas sim focar nas inquietações mentais de seus personagens ${ }^{7}$. Os verdadeiros acontecimentos não se limitam apenas a uma dimensão física, mas numa realidade oculta, acessível por meio da sondagem interior:

[...] veio da sala de jantar, segurando James pela mão, pois ele não iria com outros. Parecia-lhe tão anexo inventar divergências, quando as pessoas já as tinham em demasia. "As divergências reais são mais que suficientes", pensou, de pé junto à janela da sala de visitas. Neste momento pensava nos ricos e nos pobres, nos nobres e nos plebeus: os nobres, ela os respeitava com certa relutância, pois possuía nas veias o sangue daquela nobilíssima e algo mítica casa italiana, cujas descendentes tão trêfega e encantadoramente sussurraram e saracotearam pelos salões ingleses do século XIX. Delas herdara a inteligência, a maneira de ser e o gênio: não dos vadios ingleses ou dos frios escoceses. Preocupava-se particularmente com o problema dos ricos e dos pobres: as coisas que vira pessoalmente ali em Londres, quando visitara viúvas e esposas dedicadas, munida de uma bolsa, um caderno denotas e lápis, apontando salários e despesas, emprego e desemprego em colunas cuidadosamente dispostas para esse fim, na esperança de assim deixar de ser mulher voltada apenas para as mesma, cuja a caridade era em parte um consolo para sua própria indignação, em parte uma alívio para sua curiosidade --- pretendendo tornar-se uma pesquisadora que explicasse o fenômeno social, para que seu espírito pouco cultivado, era objeto de vívida admiração (WOOLF, 1987, p. 14-15).

É notável que aquela realidade linear deixou de ser o elemento dominante na narrativa. Agora, dá lugar ao monólogo interior, um diálogo que a própria personagem realiza consigo

\footnotetext{
5 “[...] o romance é uma expressão da época em que é produzido. Inevitavelmente refletiu as transformações pelas quais o mundo passou". (MANZANO, 2011, p.72).

${ }^{6}$ Ao desaparecer o intermediário, substituído pela presença direta do fluxo psíquico, desaparece também a ordem lógica da oração e a coerência da estrutura que o narrador clássico imprimia à sequência dos acontecimentos. Com isso, esgarça-se, além das formas de tempo e espaço, mais uma categoria fundamental da realidade empírica e do senso comum: a da causalidade (lei de causa e efeito, base do enredo tradicional, com seu encadeamento lógico de motivos e situações, com início meio e fim (ROSENFELD, 1996, p. 84).

${ }^{7} \mathrm{O}$ que interessa é o lado oculto dos seres, o processo interior dos seus personagens. Com isso, dificultarão muito o trabalho do leitor. Porque o romancista modernista descarta é aquilo de que se orgulhavam os realistas, a reprodução da realidade exterior. Descartar os detalhes esclarecedores dos fatos; o enredo, a historinha, perde importância (MANZANO, 2011, p. 76).
} 
mesmo. Este monólogo interpola com o que é narrado, gerando a sensação de estar em dois lugares diferentes ao mesmo tempo. Esse método faz com que os leitores saiam de sua zona de conforto e passem ao estado ativo, em que são obrigados a construir o sentido do que é apresentado.

Outro elemento fragmentado em Passeio ao farol foi o tempo. É fato que outrora a arte romanesca gozou de inúmeras produções que continham uma cronologia perfeita, em que as sequências dos fatos seguiam um desenrolar lógico. No entanto, com o romance moderno, isto foi totalmente desconfigurado. As narrativas perderam sua temporalidade ordenada, que dá lugar a uma pluritemporalidade distorcida e sem precisão. Sendo assim, o presente, o passado e o futuro fundiram-se; o começo, meio e fim foram suprimidos. O que resultou disto, foram conjuntos de acontecimentos que se interlaçam, formando, assim, uma amálgama atemporal indeterminada ${ }^{8}$.

As barreiras do discurso foram rompidas. O tempo da história, que é pluridimensional, libertou-se e transformou o romance num labirinto caótico. Para ratificar essas premissas, fazse mister ver o início do romance de Samuel Beckett, $O$ inominável:

ONDE AGORA? Quando agora? Quem agora? Sem me perguntar. Dizer eu. Sem pensar. Chamar isso de perguntas, hipóteses. Ir adiante, chamar isso de ir, chamar isso de adiante. Pode ser que um dia, primeiro passo, vai, eu tenho ficado simplesmente' ali, onde, em vez de sair, segundo um velho hábito, passar dia e noite tão longe de casa quando possível, não era longe. Pode ter começado assim. Não me farei mais perguntas. Você só pensa em descansar, para agir melhor depois, ou sem segundas intenções, eis que em muito pouco tempo já se está na impossibilidade de nunca fazer nada. Pouco importante como isso se deu. Isso, dizer eu, sem saber o quê. Talvez não tenha feito mais que ratificar um velho fato consumado. Mas não fiz nada de fato. Parece que falo, não sou eu, não é de mim. São algumas generalizações para começar. Como fazer, como vou fazer, que devo fazer, na situação em que estou, como proceder? Por aporia ou melhor por afirmações invalidadas à medida que são expressas, ou mais cedo ou mais tarde (BECKETT, 2009, p. 29).

Essa citação ilustra bem o processo de ruptura temporal, nada é ordenado, a coerência é comprometida, as antigas contextualizações são extintas. Como foi ilustrado, não é possível identificar nem mesmo quem fala, o que fala, e para quem se fala. Algo semelhante acontece em Passeio ao Farol, a narrativa inicia o terceiro capítulo sem nenhuma informação ao leitor, o que se vê é uma série de eventos que ocorrem rapidamente e, no mais das vezes, misturamse, tornando a leitura densa e confusa:

\footnotetext{
8 Destruirão as formas bem feitas e reestruturarão os esquemas narrativos, apresentando senas simultâneas, misturando passado presente na mente dos seus protagonistas, mente apresentada nãos mais por um onisciente, mas através da própria atividade mental dos personagens (MANZANO, 2011, p.77).
} 
Talvez você acorde e encontre o sol brilhando e os passarinhos cantando", disse ela, compassivamente, alisando o cabelo do menino, pois podia perceber que o marido, com a cáustica observação de que não faria bom tempo, tinha acabado com o entusiasmo dele. Isso de ir ao Farol, percebia ela, era uma paixão dele, e depois, como se o marido, com sua cáustica observação de que não faria bom tempo amanhã, já não tivesse dito o bastante, esse homenzinho odioso seguia batendo na mesma tecla. "Talvez faça tempo bom amanhã", disse ela, alisando o cabelo. Tudo o que podia fazer agora era admirar o refrigerador, e passar as páginas do catálogo de Lojas na esperança de encontrar algo como ancinho ou uma cafeteira que, com suas pontas dentadas e seus cabos, exigissem o máximo de habilidades e cuidados para recortar. Todos esses jovens cavalheiros parodiavam o seu marido, refletiu ela; ela dizia que ia chover; eles diziam que era furacão certo. Mas, aqui, enquanto passava páginas, sua busca da figura de um ancinho ou de uma ceifadeira foi subitamente interrompida. $O$ áspero murmúrio, irregularmente cortado pelos cachimbos sendo levados a boca de depois retirados, lhe assegurava, embora não conseguisse ouvir (sentada junto a janela) o que diziam, que homens conversavam animadamente; esse som, que já durava meia hora e que, como um bálsamo, tinha encontrado lugar na escala dos sons que lhe pressionavam a cabeça, tal como, de quando em quando, o estalido das bolas contra os tacos, o agudo e repentino grito (Valeu? Valeu?) das crianças jogando críquete, tinha parado; de maneira que o monótono quebrar das ondas na praia, que, na maior parte do tempo, dava uma compassada e calmante cadência aos seus pensamentos (WOOLF,2013, p. 15-16).

Esse fragmento ratifica a falta de ordenamento temporal e supressão de qualquer contextualização. Tudo é rápido e lendo ao mesmo tempo. Ora a personagem busca figuras num catálogo, ora questiona o marido e seus amigos a respeito do clima. São ações que procedem simultaneamente em dois campos, o mental e o físico. Porém, a passagem de um para outro, como é perceptível no fragmento, não possui qualquer interferência de narrador ou de regras de tempo e espaço, ela ocorre livremente.

Consequentemente, a escritora inglesa aplica uma nova técnica para apresentar o íntimo de seus personagens. Ela usa o fluxo de consciência. Esse nada mais é do que a impressão da mente dos personagens nas páginas do romance “[...] a consciência da personagem passa a manifestar-se na sua totalidade imediata, em pleno ato presente, como um "Eu" que ocupa totalmente a tela imaginária do romance" (ROSENFELD,1996, p.84).

Embora possa ocorrer ao lado no monólogo interior, o fluxo de consciência distinguese por quebrar as barreiras do tempo e espaço, anulando, desta forma, a ordem narrativa ${ }^{9}$. Tal procedimento assemelha-se a mente humana, a qual não é apiedada ao controle nem se sujeita a normas cronológicas. "O fluxo não obedece ao tempo cronológico, mas ao tempo psicológico" (MANZANO, 2011, p. 81). Por isto, Virginia Woolf pode revelar o interior de seus personagens e seus pensamentos mais ocultos e suas ambições mais complexas.

\footnotetext{
${ }^{9}[\ldots]$ a tentativa de reprodução do fluxo de consciência significa uma ruptura no tempo cronológico - não haverá mais narrativas com a história contata com princípio, meio e fim, pois passado e presente estão juntos simultaneamente na mente (MANZANO, 2011, p.81-82).
} 
É quase impossível tentar transcrever todo o curso do fluxo de consciência em Passeio ao farol, uma vez que sua duração abrange várias páginas. Entretanto, no capítulo dezessete da primeira parte, é possível acompanhar o desenvolver desta novíssima técnica, porém, como sua duração é de praticamente de vinte seis páginas, convém limitar-se ao início do fluxo:

Mas o que fiz da minha vida? Pensou a Sra. Ramsay, tomando seu lugar na cabeceira, e observando a todos aqueles pratos que formavam círculos brancos sobre a mesa. "William, sente-se ao meu lado", disse Lily, disse ela, cansadamente, lá. Eles tinham aquilo - Paul Rayley e Minta Doyle, ela, somente isto - uma mesa infinitamente longa e pratos e facas. No outro extremo sentava-se o marido, prostrado, franzindo o cenho. A quê? Ela não sabia. Ela não se importava. Não podia compreender como alguma vez sentira qualquer emoção ou afeição por ela. Ela Tinha a sensação, enquanto servia sopa, de estar além de tudo, no fim de tudo, fora de tudo, como se houvesse um turbilhão - ali - e se poderia estar nele, ou se poderia estar fora dele, e ela estava fora dele. Tudo chegara ao fim, pensou, enquanto eles chegavam, um após o outro, Charles Tansley - "Sente-se ali, por favor", disse ela -, Augustus Carmichael - e se sentou. Enquanto isso, esperava, passivamente, que alguém lhe respondesse, que algo acontecesse. Mas isso, pensou ela, servindo a sopa, não é coisa que se diga. Erguendo as sobrancelhas diante da discrepância - aquilo era o que estavas pensando -, isto era o que estava fazendo - servindo a sopa -, sentiu-se, cada vez mais fortemente, fora do turbilhão; ou, como se uma sombra tivesse baixado, e, despojado da cor, ela visse as coisas verdadeiramente. A sala (ela olhou em redor) estava muito deteriorada. Não havia beleza em lugar algum. Ela evitara olhar para o Sr. Tansley. Nada parecia ter se reunido. Todos eles se sentavam separados. E todo esforço feito para reunir e fazer fluir criar ficava novamente a seu cargo. De novo, sentiu, sem hostilidade, como um fato, a esterilidade dos homens, pois ela se não o fizesse ninguém o faria (WOOLF, 2013, p.73-74).

É perceptivo, no trecho acima, que os pensamentos dos personagens se interlaçam, assim como a voz do narrador que se funde com a mente da Sra. Ramsay, o que torna a leitura mais complexa. O tempo fica indeterminado com o prosseguir do capítulo e o fluxo de consciência se torna mais intenso gradualmente.

Outra observação relevante, no que tange aos elementos de ruptura e experimentação em Passeio ao Farol, é a eliminação do nome dos personagens centrais. Destes, sabe-se apenas o sobrenome, mas não seu primeiro nome. Isso remete a um processo comum ao espírito modernista, a redução do homem a um ser vazio, sem identidade ${ }^{10}$. Em outras palavras, aquela bolha protetora, no qual o homem antigo se apoiara, rompeu-se. Não havia mais os deuses nem as consolações metafísicas para alienar o homem, agora, ele foi abandonado a sua própria sorte, tornou-se solitário:

\footnotetext{
${ }^{10}$ Compreendemos agora mais de perto o porquê a personalidade individual tinha de desfazer-se e tornar-se abstrata no processo técnico descrito: para que se revelem tanto melhor as configurações arquetípicas do ser humano (ROSENFELD, 1996, p.89).
} 
Um verdadeiro despropósito para o grego! O céu estrelado de Kant brilha agora somente na noite escura do puro conhecimento e não ilumina mais os caminhos de nenhum dos peregrinos solitários- e no Novo Mundo, ser homem significa ser solitário. E a luz interna não fornece mais do que ao passo seguinte a evidência- ou a aparência- de segurança. De dentro já não irradia mais nenhuma luz sobre o mundo dos acontecimentos e sobre o seu emaranhado alheio à alma. E quem poderá saber se a adequação do ato à essência do sujeito, o único ponto de referência que restou, atinge realmente a substância, uma vez que o sujeito se tornou uma aparência, um objeto para si mesmo; uma vez que sua essencialidade mais própria e intrínseca lhe é contraposta apenas como exigência infinita num céu imaginário do dever-ser; uma vez que ela tem de emergir de um abismo inescrutável que reside no próprio sujeito, uma vez que a essência é somente aquilo que se eleva desse fundo mais profundo e ninguém jamais foi capaz de pisar-lhe ou visualizar-lhe a base? A arte, a realidade visionária do mundo que nos é adequado, tornou-se assim independente: ela não é mais uma cópia, pois todos os modelos desapareceram; é uma totalidade criada, pois a unidade natural das esferas metafísicas foi rompida para sempre (LUKÁCS, 2000, p.34).

O homem, fechado em seu egoísmo antropocêntrico, destruiu a si mesmo. Desceu de seu status quo de ser supremo para a monstruosidade de um inseto, tornou-se um ser solitário, abandonado e sufocado pela sua própria liberdade ${ }^{11}$. Em outras palavras, ele passou pelo processo de "desumanização". Ou seja, ele perdeu suas características humanas ou qualquer resquício de identidade, tornou-se uma sombra indefinida. Ou, conforme Lukács, tornou-se aparência, um objeto a si mesmo.

Por isso, criaram-se romances com personagens sem nomes, como o já citado Inominável de Beckett e alguns personagens de Kafka, como Josef $\mathrm{K}$, de O Processo. Vale ressaltar que, em a Metamorfose, mesmo que o personagem possua um nome, sua identidade como homem foi desconstruída quando Gregor, protagonista do romance mencionado, metamorfoseou-se num inseto.

Logo, ausência dos nomes em Passeio ao farol evidencia que o homem da primeira metade do século XX estava em crise consigo mesmo, não tinha a quem recorrer nem onde esconder. Ele foi vítima de seu próprio egoísmo, e como herança de suas ações recebeu a destruição e aniquilação de sua essência.

Sendo assim, Passeio ao Farol atesta duas realidades inerentes ao romance: uma estética-literária e outra sociológica. A primeira ratifica que o romance não é um gênero calcificado, mas vivo, que caminha conforme a humanidade e adequa-se as suas diversas fases,

\footnotetext{
${ }^{11}$ [...] O homem é livre, o homem é liberdade. Por outro lado, se Deus não existe, não encontramos, já prontos, valores ou ordens que possam legitimar a nossa conduta. Assim, não teremos nem atrás de nós, nem na nossa frente, no reino luminoso dos valores, nenhuma justificativa nenhuma desculpa. Estamos sós, sem desculpas. É o que posso expressar dizendo que o homem está condenado a ser livre. Condenado, porque não criou se criou a si mesmo, e como, no entanto, é livre, uma vez que foi lançado no mundo, é responsável por tudo que faz (SARTRE, 1970, p.7).
} 
tornando-se, por meio do processo de ruptura e experimentação, sempre atual. O segundo item corresponde à memória coletiva da Primeira Guerra Mundial. Elas irão expressar-se na forma de produções artísticas que retratarão, ora de forma mais intensa, ora mais atenuada ou até mesmo fantástica, o caos e a monstruosidade da Guerra.

\section{Considerações finais}

Sem sombra de dúvida, o romance moderno capitou e incorporou, na sua realidade interna, aquilo que já se vivenciava externamente. Ou seja, os elementos sociais se tornaram agentes da estrutura deste novo tipo de romance, por isto as produções artísticas gozaram de um espírito de ruptura radical "[...] Sabemos, ainda, que o externo (no caso, o social) importa, não como causa, nem como significado, mas como elemento que desempenha um certo papel na constituição da estrutura, tornando-se, portanto, interna” (CANDIDO,2014, p.14).

A obra Passeio ao farol, de Virginia Woolf, assim como muitas outras produções do período da primeira metade do século XX, compartilharam da linha estética comentada. Aplicando, em suas obras literárias, o caos e o desespero provocado pela Primeira Grande Guerra: “[...] A guerra privou uma boa parte da vida que havia e poderia haver no interior de cada ser humano. Quem a viveu não pôde dela desvincular-se sem prejuízos e mutilações físicas e espirituais" (ZUIN, 2001, p. 88).

A memória coletiva, ao se tratar da temática da Primeira Guerra, não se restringe à simples descrição do fato em si, mas está na própria composição do romance moderno. Ele própria é a memória daquele período. Não foi ocasional que a estrutura linear, a noção de tempo e espaço tenham sido rompidas; era necessário que tais alterações ocorressem para que o próprio gênero se adequasse aos eventos que subjugavam e aniquilavam a existência humana naquela fase. Sendo assim, em Passeio ao Farol, a memória da guerra está na própria composição do romance. Toda a sua desconstrução e inovação estéticas são reflexos das catástrofes provocada pelas investidas bélicas. Woolf anexou nas páginas de sua obra o desespero, o silêncio e a falta de perspectiva que vivenciavam os combatentes que iam e voltavam dos confrontos.

Por isso, seu romance não tem um narrador perfeito que conduz o leitor durante a narrativa, nem uma concepção temporal que vá coordenando os eventos narrados. Tudo agora é morto, frio, sem esperança ou som, a narrativa se transformou num caos. Nada é lógico ou bem definido, o único sentimento coletivo é o medo seguido dum mortal silêncio ${ }^{12}$.

\footnotetext{
${ }^{12} \mathrm{Na}$ época, já se podia notar que os combatentes tinham voltado silenciosos do campo de batalha. Mais pobres em experiências comunicáveis, e não mais ricos (BENJAMIN, 1987, p.115).
} 


\section{Referências}

AUERBACH, Erich. A meia marrom. In: Mimeis. A representação da realidade na literatura ocidental. São Paulo: perspectiva, 2009.

BAKHTIN, Mikhail. Epos e romance. Questões de literatura e de estética: a teoria do romance. Tradução de Aurora Bernardini et al. 4. ed. São Paulo: Editora UNESP,1988.

BECKETT, Samuel. O inominável. Tradução de Ana Helena de Souza. São Paulo: Globo, 2009.

BENJAMIN, Walter. Magia e técnica arte e política: ensaios sobre literatura história e cultura. Tradução de Sérgio Paulo Rouanet. $3^{a}$ ed. São Paulo: Brasiliense, 1987.

BOSI, Ecléa. Memória e sociedade: lembranças de velhos. 2 ed. São Paulo: Editora da Universidade de São Paulo, 1987.

CARPEAUX, Otto Maria. História da literatura ocidental. 10 ed. Brasília: Senado Federal, 2011. v. 4 (volume citado).

CANDIDO, Antonio. Literatura e sociedade: estudos de teoria e história literária. 13. ed. Rio de Janeiro: Ouro sobre azul, 2014.

DEFINA, Gilberto. Teoria e prática de análise literária. São Paulo: Pioneira, 1975.

D'ONOFRIO, Salvatore. Literatura ocidental: autores e obras fundamentais. São Paulo:

Ática, 2007.

HELLER, Agnes. O cotidiano e a história. Tradução de Carlos Nelson Coutinho; Leandro Konder. 6. ed. São Paulo: Terra e Paz S/A, 2000.

HOBSBAWM, E. Historiker wie auf Urlaub. Eric Hobsbawm im Gespräch mit Daniel Haufler. Neue Rundschau, Heft 4, 1996.

HALBWACHS, Maurice. A memória coletiva. Tradução de Laurent Léon Schafdter. 2. ed. São Paulo: Vértice, 1990.

LUKÁCS, Georg. Culturas fechadas. A teoria do romance. Tradução de José Marcos Mariani de Macedo. São Paulo: Duas Cidades/ Editora 34, 2000.

MANDER, Herbert. Virginia Woolf: a medida da vida. Tradução de Leonardo Fróes. São Paulo: Cosac Naify,2011.

MANZANO, Thais Rodegheri. E se a literatura se calasse? São Paulo: Terceiro Nome, 2011.

MANZANO, Thais Rodegheri. Artimanhas da ficção: Ensaios de literatura. São Paulo: Editora Terceiro Nome, 2008.

NUNES, Benedito. O tempo na narrativa. 2 ed. São Paulo: Ática, 1988. 
ROSENFELT, Anatol. Reflexões sobre o romance moderno. $5^{\mathrm{a}}$ ed. São Paulo: Perspectiva, 1996.

TALES, Gilberto Mendonça. Vanguarda europeia e modernismo brasileiro: apresentação e crítica dos principais manifestos vanguardistas. 3. ed. Petrópolis: vozes, 1976.

THOMSON, Devid. Pequena história do mundo contemporâneo. Tradução de J.C Teixeira Rocha. Rio de Janeiro: Zahar Editôres, 1967.

TODOROV, Tzvetan. Les catégorics du récit littéraire. Communications. Paris: Seuil, n.8, 1966.

WOOLF, Virginia. Ao farol. Tradução de Tomaz Tadeu. Belo Horizonte: Autêntica, 2016.

WOOLF, Virginia. Passeio ao farol. Tradução de Luiza Lobo. Rio de Janeiro: Rio Gráfica, 1987.

WOOLF, Virgínia. Um teto todo seu. Tradução de Bia Nunes de Sousa. São Paulo: Tordesilhas, 2014.

ZUIN, João Carlos Soares. A crise da modernidade no início do século XX. Estudos de Sociologia, Araraquara, v. 6, n. 11, p. 67- 90, 2001. 